\title{
Karakteristik dan Sebaran Sampah Terdampar di Kawasan Pesisir \\ Taman Nasional Bali Barat
}

\author{
Putra Bagus Panji Pamungkas a, I Gede Hendrawan ${ }^{a^{*}}$, I Nyoman Giri Putra ${ }^{a}$
}

\begin{abstract}
${ }^{a}$ Program Studi Ilmu Kelautan, Fakultas Kelautan dan Perikanan, Unuversitas Udayana, Bali, Indonesia
*Corresponding author, email:hendrawan@gmail.com
\end{abstract}

\section{ARTICLE INFO}

Article history:

Received: July $23^{\text {th }} 2020$

Received in revised form: August $24^{\text {th }} 2020$

Accepted: November $5^{\text {th }} 2020$

Available online: February $28^{\text {th }} 2021$

Keywords:

Conservation; Marine debris; National park; Plastic; Pollution; West Bali

\section{AB S T RACT}

\begin{abstract}
The existence of marine debris can be a threat to marine ecosystems. Several studies have shown that marine debris can cause death of marine organisms and a degradation of ecosystems. The West Bali National Park (TNBB) is a conservation area in Bali that is also susceptible to be affected by marine debris pollution, due to its high population and anthropogenic activity in the area. Bali generates about 4.281 tons of waste per day, where $11 \%$ of it ends up in the ocean. Therefore, research about marine debris in TNBB is important. The purpose of this research is to find out the characteristics and distribution of stranded marine debris in the TNBB coastal area. This research was conducted in February 2020 at 23 stations by the shoreline. Marine debris data collection was carried out by adapting the method developed by the Commonwealth Scientific and Industrial Research Organization (CSIRO) Global Plastic Pollution Project. Marine debris exists along the coastline with the concentration range between $0.05-28.47 \mathrm{items} / \mathrm{m} 2$ with the average of 4.29 items $/ \mathrm{m} 2$. As much as $92.3 \%$ of waste were plastic, dominated by three major debris classes, including soft plastic (44.8\%), foam (30.8\%), and hard plastic (12.4\%). Marine debris in the area has various sizes and shapes. As much as $57.9 \%$ of debris at TNBB were whole items and the rest of it were fragment items. Marine debris size at TNBB tend to have a big relative size, i.e. between $8-16 \mathrm{~cm}(32 \%)$. Generally, marine debris at TNBB were mostly daily consumer items. Therefore, public awareness play an important role to decrease the amount of marine debris on the TNBB coastal area.
\end{abstract}

2020 JMRT. All rights reserved.

\section{Pendahuluan}

Menurut National Oceanic and Atmospheric Administration (NOAA), sampah laut merupakan bahan padat persisten yang diproduksi atau diproses dan secara sengaja atau tidak sengaja terbuang atau ditinggalkan di lingkungan laut. (Lippiatt et al. 2013). Sampah laut dapat berupa plastik, logam, kaca, karet, kertas / kayu olahan, kain, dan sampah lainnya yang tidak diketahui (Lippiatt et al., 2013). Isu sampah laut semakin marak ketika diangkat pada laporan UNEP tahun 2011 dan konferensi Rio +20 tahun 2012 terkait dengan isu keberadaan sampah laut yang mengancam kesehatan lingkungan dan keanekaragaman laut sehingga dihasilkan komitmen untuk aksi pengurangan dampak dan keberadaan sampah laut di lingkungan pada tahun 2025 (UNEP, 2011; UN, 2012).

Sampah laut dapat menimbulkan beberapa masalah yakni sebagai media transportasi atau penghasil kontaminan pencemar, persebaran spesies invasif, mempengaruhi isu sosial ekonomi masyarakat dan menyebabkan masalah pada keberlangsungan organisme laut dan ekosistemnya (UNEP, 2014). Tercatat bahwa lebih dari 800 spesies organisme laut dan pesisir terdampak oleh pencemaran sampah akibat menelan dan terlilit sampah laut (SCBD, 2016). Sampah laut dapat menjadi masalah serius di kawasan pesisir dan pulau-pulau kecil Indonesia yang merupakan habitat dari organisme laut dan ekosistemnya (Purba et al., 2017). Berdasarkan hasil penelitian dari Jambeck et al. (2015), Indonesia menempati peringkat ke-2 sebagai penghasil sampah plastik terbesar di dunia setelah Cina dengan buangan ke laut mencapai 0,48-1,29 MMT per tahun. Hal tersebut tentunya berkaitan dengan keberadaan sampah tidak terkelola di berbagai provinsi di Indonesia, seperti halnya Provinsi Bali yang mana menurut penelitian Bali Partnership (2019), sebanyak 52\% sampah di Bali tidak terkelola dengan baik (2.220 ton sampah per hari).

Sampah dapat dihasilkan dari berbagai kegiatan yang dilakukan baik di darat maupun di laut, seperti halnya aktivitas di kawasan permukiman, aktivitas industri, aktivitas lepas pantai dan aktivitas lainnya yang berada di pulau Bali. Bali menghasilkan 4.281 ton sampah per hari (Bali Partnership, 2019), yang mana sebanyak 53\% sampah di Bali dapat bersumber dari rumah tangga, 13,2\% pasar tradisional, 4,5\% fasilitas publik, 4,1\% dari pusat perniagaan dan lain sebagainya (DPS, 2018). Dari keseluruhan sampah yang dihasilkan di pulau Bali, sebanyak 11\% sampah diperkirakan berakhir di laut dan mencemari kawasan pesisir pulau Bali dengan kelimpahan sampah berkisar $0-7,15 \mathrm{buah} / \mathrm{m}^{2}$ dengan sampah dominan berupa sampah plastik lunak, sampah plastik keras dan sampah busa (foam) dengan persentase masing-masing 
sebesar 45\%, 15\% dan 13\% (Bali Partnership, 2019; Hendrawan et al., 2019).

Pergerakan sampah di laut tidak mengenal batas, sehingga sampah laut juga dapat berakhir dan terakumulasi di kawasan konservasi. Kawasan konservasi laut merupakan suatu wilayah yang ditetapkan sebagai kawasan pelestarian sumber daya laut. Menurut Li (2002) kawasan konservasi memiliki beberapa manfaat, diantaranya sebagai bentuk perlindungan terhadap spesies endemik dan spesies langka, menjaga keanekaragaman hayati, peningkatan produksi ikan, perlindungan pemijahan, pengurangan mortalitas ikan, hingga manfaat kepada sosial ekonomi masyarakat. Keberadaan sampah laut dapat menjadi sebuah ancaman bagi kawasan konservasi dalam menjalankan fungsinya Persebaran sampah laut di kawasan konservasi memungkinkan terjadinya kematian organisme laut, serta penyebaran spesies invasif dan senyawa kimia berbahaya sehingga dapat membahayakan ekosistem dengan pergeseran komposisi spesies dan biomagnifikasi polutan (Pawar et al., 2016; SCBD, 2016).

Meskipun pada umumnya kawasan konservasi merupakan kawasan yang dilindungi dari berbagai aktivitas yang bersifat merusak, keberadaan sampah dapat tetap ditemukan di kawasan konservasi laut. Beberapa penelitian dan pembersihan pantai menunjukkan bahwa pencemaran sampah laut juga terjadi di kawasan konservasi, seperti kawasan konservasi penyu Timur Laut Brazil, Cagar Alam Pelagos laut Mediterranean, Pulau Biawak dan kawasan konservasi laut Sabah. Sampah yang ditemukan pada kawasan-kawasan tersebut didominasi oleh sampah berbahan dasar plastik dengan persentase berkisar 52-94\% (Sul et al., 2011; MPAnews, 2011; Fossiet al., 2017; Purba et al., 2017). Fakta tersebut dapat menjadi ancaman bagi kawasan konservasi di Indonesia, mengingat Indonesia memiliki luas kawasan konservasi perairan, pesisir dan pulau-pulau kecil seluas 19.144.694,28 ha (KKP, 2017).

Taman Nasional Bali Barat (TNBB) merupakan salah satu kawasan konservasi di Indonesia yang juga rentan terdampak pencemaran sampah. Sebagaimana kawasan konservasi TNBB berada di pulau Bali, sebanyak 52\% sampah di Provinsi Bali belum terkelola dengan baik (Bali Partnership, 2019). Selain itu kawasan TNBB juga berseberangan dengan pulau Jawa, khususnya Provinsi Jawa Timur yang mana berdasarkan laporan Dinas Lingkungan Hidup Provinsi Jawa Timur (2017), pengelolaan sampah menjadi isu lingkungan hidup prioritas ke-2 di Jawa Timur. Tingginya jumlah populasi di suatu daerah berkontribusi pada banyaknya timbulan sampah, sebagaimana Bali dan Jawa Timur memiliki populasi masing-masing sebesar 4.200.000 dan 39.292.972 jiwa (DLH, 2017; Bali Partnership, 2019).

Ancaman tersebut dapat menjadi tantangan tersendiri bagi ekosistem di kawasan TNBB, sebagaimana kawasan konservasi TNBB memiliki ekosistem laut seperti halnya ekosistem terumbu karang, padang lamun dan juga ekosistem mangrove. Dengan demikian studi mengenai karakteristik dan sebaran sampah laut terdampar di kawasan pesisir TNBB perlu untuk dilakukan. Sehingga melalui penelitian ini, dapat dihasilkan informasi yang dapat dipergunakan sebagai data acuan baik bagi pemerintah, maupun pemangku kepentingan lainnya terkait dalam strategi penetapan dan atau evaluasi kebijakan mengenai sampah sebagai pencemar lingkungan pesisir di kawasan konservasi TNBB.

\section{Metodologi}

\subsection{Waktu dan Tempat Penelitian}

Pendataan sampah di sepanjang pantai dilakukan pada bulan Februari 2020, bertempat di kawasan pesisir Taman Nasional Bali Barat (TNBB). Berdasarkan Surat Keputusan Menteri Kehutanan
No.493/Kpts-II/1995, kawasan TNBB berada di Kabupaten Buleleng dengan luas 12.814,89 Ha dan di Kabupaten Jembrana seluas 6.188,00 Ha. Kawasan TNBB terdiri dari Hutan Lindung Bali Barat, Suaka Margasatwa Bali Barat dan Suaka Margasatwa Pulau Menjangan beserta laut sekitarnya dengan luas total sebesar 19.002,89 Ha. Luas wilayah darat sebesar 15.587,89 Ha dan luas wilayah laut sebesar 3.415,00 Ha (Mahmud et al., 2016).

Dalam penentuan titik lokasi stasiun pengamatan, tidak diberlakukan kriteria tertentu pada lokasi yang dipilih. Sehingga seluruh lokasi ditentukan secara acak di sepanjang garis pantai dan memiliki kesempatan yang sama untuk dipilih menjadi titik lokasi pengamatan. Penyebaran pemilihan titik secara acak dilakukan dengan menentukan jarak tertentu antar titik sehingga didapatkan jumlah titik stasiun pengamatan tertentu yang dapat dianggap mewakili kawasan pesisir TNBB. Dengan digunakannya $4 \mathrm{~km}$ jarak antar titik di bagian Bali Barat dan juga $1 \mathrm{~km}$ di bagian pulau Menjangan, maka didapatkan, 23 titik stasiun pengamatan yang mencakup kawasan Bali Barat (16 titik) dan kawasan pulau Menjangan (7 titik) (Gambar 3).

\subsection{Metode Pendataan Sampel}

Pengambilan data sampah terdampar dilakukan dengan mengadaptasi metode yang dikembangkan oleh Commonwealth Scientific and Industrial Research Organization (CSIRO) Global Plastic Pollution Project (Schuyler et al., 2018), yang dilakukan dengan membuat 3 transek secara tegak lurus pada tiap stasiun pengamatan dimulai dari garis air hingga 2 meter di belakang vegetasi pantai. Setiap transek digelar dengan jarak sejauh 50 meter antara satu sama lain (Gambar 1). Pendataan sampah dilakukan pada area sisi kanan dan kiri transek masing-masing selebar 1 meter. Sampah yang masuk pada pendataan hanyalah sampah yang terlihat di permukaan.

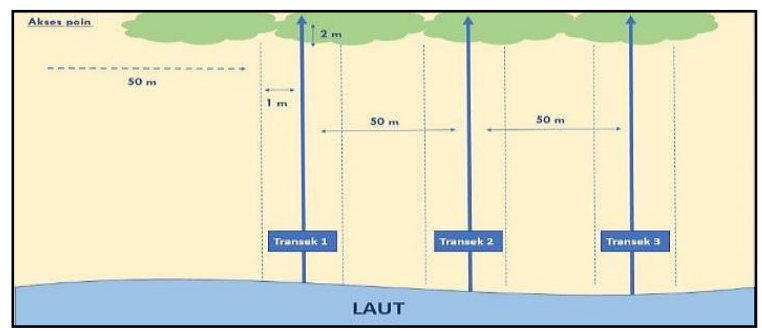

Gambar 1. Ilustrasi penarikan transek (Schuyler et al., 2018).

Pada tiap transek dicatat beberapa parameter berupa jumlah dan jenis sampah, ukuran dan kondisi bentuk sampah, titik koordinat pada titik mulai dan titik akhir transek, total panjang transek, serta durasi pendataan. Adapun jenis sampah dikategorikan ke dalam 13 kategori kelas sampah, diantaranya adalah kelas hard plastic, soft plastic, plastic straps, metal, glass, rubber, foam, paper, fishing, timber, cloth, miscellaneous dan other (Lampiran 2). Ukuran sampah terbagi menjadi 7 kategori, yang mana kategori I berukuran $(0-1 \mathrm{~cm})$, II $(1-2 \mathrm{~cm})$, III $(2-4 \mathrm{~cm})$, IV $(4-8 \mathrm{~cm}), \mathrm{V}(8-16 \mathrm{~cm})$, VI $(16-21 \mathrm{~cm})$ dan VII $(>21 \mathrm{~cm})$. Kondisi bentuk sampah terbagi menjadi 2 kategori, yaitu sampah berbentuk utuh (whole) dan tidak utuh (fragment). Informasi mengenai karakteristik pantai juga dicatat, yaitu diantaranya tipe bentuk pantai, aspek (arah pantai menghadap laut), tipe dan warna substrat, kemiringan pantai dan tipe belakang pantai.

\subsection{Analisis Data}

Konsentrasi sampah menggambarkan banyaknya jumlah sampah pada suatu unit area. Konsentrasi sampah laut dihitung berdasarkan rumus konsentrasi berikut (Lippiatt et al., 2013): 
$\mathrm{C}=\mathrm{n} /(\mathrm{w} \times \mathrm{l})$

C merupakan konsentrasi sampah (buah $/ \mathrm{m}^{2}$ ), $\mathrm{n}$ adalah total sampah, w adalah lebar transek (m), dan 1 adalah panjang transek (m). Setelah konsentrasi sampah dihasilkan di setiap titik, selanjutnya nilai konsentrasi akan dipetakan sebagai peta sebaran konsentrasi sampah di kawasan TNBB secara spasial.

Karakteristik sampah laut dianalisa berdasarkan persentase kelas sampah, jenis sampah, ukuran sampah dan bentuk sampah (utuh/tidak utuh). Adapun perhitungan persentase kelas, jenis, ukuran dan bentuk sampah dihitung dengan menggunakan rumus sebagai berikut:

$\mathrm{Pi}=\frac{x i}{\sum_{i=1}^{n} x i} \times 100 \%$.

Pi merupakan persentase kelas, jenis, ukuran atau bentuk sampah ke-i, serta xi merupakan total kelas, jenis, bentuk atau ukuran sampah ke-i.

\section{Hasil dan Pembahasan}

\subsection{Konsentrasi Sampah}

Dari 69 transek yang mewakili 23 titik stasiun pengamatan (3 transek per stasiun), didapatkan konsentrasi sampah berkisar 0,05$28,47 \mathrm{buah} / \mathrm{m}^{2}$ dengan nilai rata-rata $4,29 \mathrm{buah} / \mathrm{m}^{2}$ dan nilai median $2,56 \mathrm{buah} / \mathrm{m}^{2}$ (Gambar 2).

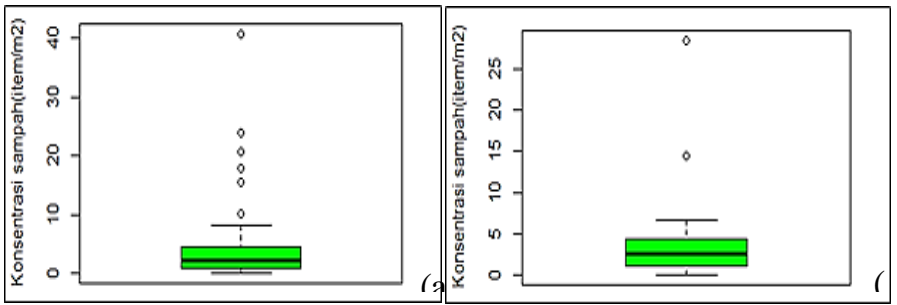

Gambar 2. Boxplot nilai konsentrasi pada 69 transek (a), dan pada nilai konsentrasi rata-rata per titik stasiun (b).

Rentang nilai konsentrasi di kawasan pesisir TNBB cenderung lebih besar jika dibandingkan dengan hasil penelitian Hendrawan et al. (2019) pada pendataan bulan Februari 2018 di seluruh kawasan pesisir pulau Bali dengan rentang konsentrasi berkisar 0$3,64 \mathrm{buah} / \mathrm{m}^{2}$ dengan nilai rata-rata sebesar $0,96 \mathrm{buah} / \mathrm{m}^{2}$.

Sampah di kawasan TNBB tersebar di seluruh sisi kawasan, yang mana kawasan yang paling terdampak dengan tingginya nilai konsentrasi sampah adalah di bagian barat daya Pulau Menjangan
(Gambar 3). Sampah di sepanjang kawasan Desa Melaya hingga Desa Gilimanuk (6 titik stasiun) memiliki kisaran konsentrasi sebesar 0,52-6,68 buah/ $\mathrm{m}^{2}$. Pada kawasan Desa Sumber Klampok (9 titik) konsentrasi sampah berkisar $0,05-4,36 \mathrm{buah} / \mathrm{m}^{2}$, pada kawasan Desa Pejarakan (1 titik) konsentrasi sampah sebesar 3,83 buah $/ \mathrm{m}^{2}$. Serta pada kawasan pulau Menjangan (7 titik) memiliki rentang konsentrasi sampah berkisar 0,58-28,47 buah $/ \mathrm{m}^{2}$.

Konsentrasi sampah terendah berada di kawasan mangrove Desa Gilimanuk dan Desa Sumber Klampok (titik 6, 7 \& 14) dengan rentang konsentrasi berkisar 0,05-0,52 buah/ $\mathrm{m}^{2}$. Hal ini disebabkan oleh lebatnya mangrove di kawasan terluar sehingga sampah akan sulit masuk ke titik lokasi stasiun pengamatan yang berada di kawasan mangrove terdalam. Berbeda halnya dengan kawasan mangrove di pulau Menjangan (titik 22 \& 23) yang menunjukkan angka konsentrasi tinggi berkisar 14,53-28,47 buah $/ \mathrm{m}^{2}$. Hal ini disebabkan oleh dekatnya bagian mangrove terdalam (titik stasiun pendataan) dengan laut, serta rapatnya akar mangrove bertipe akar pensil dan tunjang di bagian terluar. Sehingga akumulasi sampah terjadi ketika sampah dibawa masuk saat pasang, kemudian sampah akan terjebak pada akar dan tidak dapat kembali ke laut saat air kembali surut. Hal ini berkenaan dengan keberadaan outlier (Gambar 2.), dan tingginya nilai konsentrasi sampah di barat daya Pulau Menjangan (Gambar 3.).

Walaupun kawasan pesisir TNBB secara umum memiliki keterbatasan aksesibilitas oleh warga sekitar (kawasan tertutup), sampah laut tetap berlimpah di kawasan pesisir TNBB walaupun pihak Balai Taman Nasional selalu mengadakan kegiatan pembersihan pantai di beberapa titik lokasi. Menurut Thompson et al. (2004) walaupun peraturan undang-undang dan aksi untuk membatasi timbulan sampah laut telah direalisasikan, keberadaan sampah laut dapat tetap ditemukan di beberapa lokasi dan bahkan juga dapat meningkat. Seperti halnya sampah plastik, sebagian besar plastik tidak terurai di lingkungan sehingga sampah dapat meningkat seiring dengan berjalannya waktu (Andrady, 2011).

Selain itu dikarenakan daya apung dan ketahanannya, plastik dapat menempuh jarak yang jauh. Telah dilaporkan bahwa plastik yang jatuh dari kargo kapal mampu menempuh jarak sejauh 10.000 km dalam waktu lebih dari satu dekade sehingga sampah plastik dapat memiliki efek jangka panjang di lautan (Barnes et al., 2009). Pergerakan sampah di laut tidak mengenal batas, bahkan bukan hanya sampah yang terlihat di pantai saja yang menjadi sebuah permasalahan. Studi yang dilakukan di sepanjang pesisir Eropa menunjukkan bahwa terdapat akumulasi sampah di dasar laut, yang mana komponen penyusun sampah terbesar berupa sampah plastik mencapai $70 \%$ (Galgani et al., 2000).

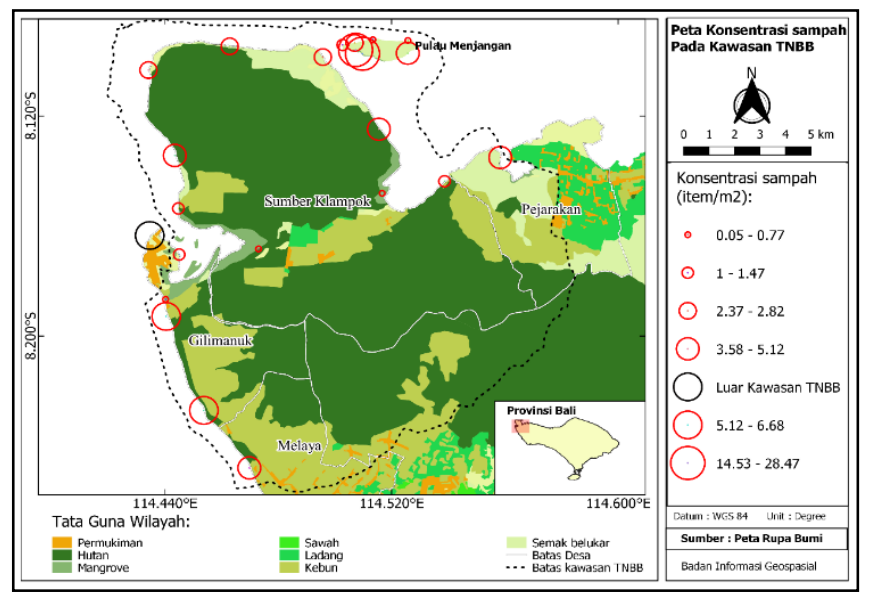

Gambar 3. Sebaran konsentrasi sampah di kawasan TNBB. Ukuran lingkaran menunjukkan besarkecilnya nilai konsentrasi sampah 


\subsection{Karakteristik Sampah}

\subsubsection{Kelas dan Jenis Sampah}

Berdasarkan pendataan yang dilakukan pada 69 transek, didapatkan total sampah tercatat berjumlah 7.009 buah sampah. Sampah yang paling dominan adalah sampah plastik yakni sebesar $92 \%$ (6.460 buah) yang terdiri dari kelas soft plastic (plastik lunak) mencapai angka 44,8\%, kelas foam (busa) 30,8\%, hard plastic (plastik keras) 12,4\%, plastic straps (tali plastik) 3,4\% dan fishing (sampah pancing) 0,5\%. Kemudian diikuti oleh sampah nonplastik sebesar $8 \%$ (549 buah) yang terdiri dari kelas rubber (karet) sebesar 3,2\%, glass (kaca) 1,6\%, cloth (kain) 1,1\%, miscellaneous (lainnya) $0,7 \%$, timber (kayu ) $0,6 \%$, metal 0,4\%, paper (kertas) $0,2 \%$ dan other (sampah lain) $0,1 \%$ (Gambar 4).

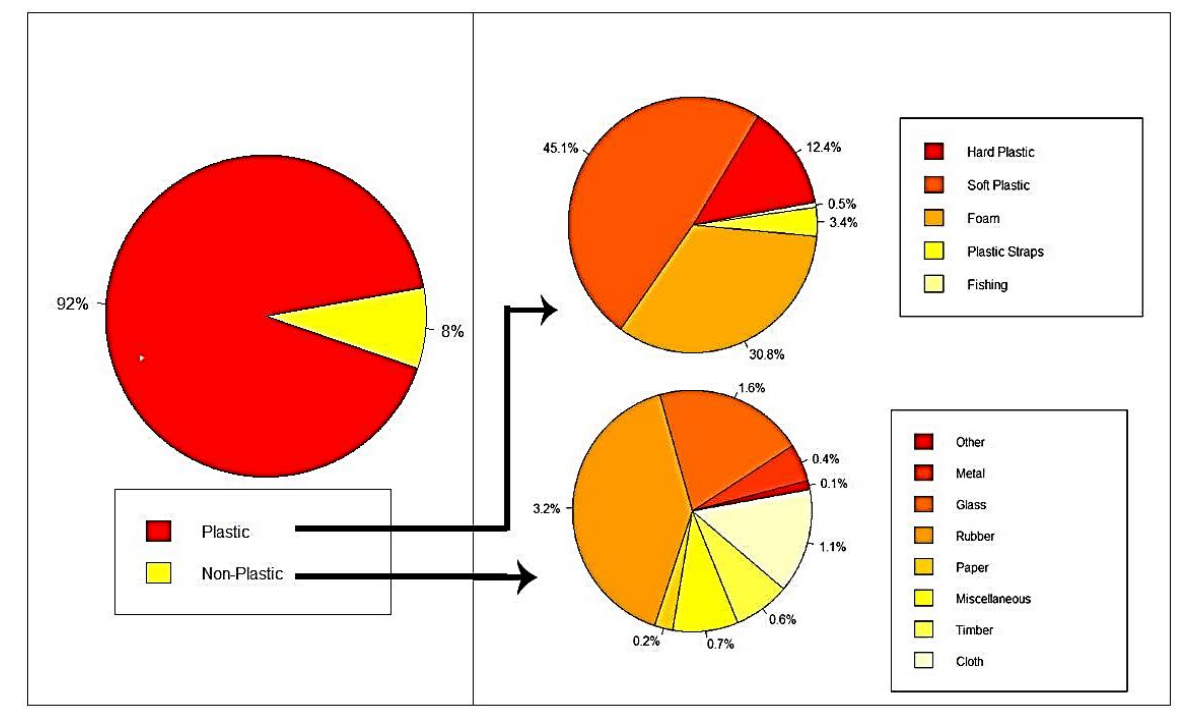

Gambar 4. Persentase kelas sampah di kawasan pesisir TNBB.

Jenis sampah plastik yang paling banyak ditemukan berupa sampah pembungkus makanan/label, wadah makanan foam/busa, plastik pembungkus, polystyrene, gelas plastik, sedotan, plastik keras dan lunak lain/yang tidak diketahui, tali, sepatu/sandal dan juga perkakas makan. Sampah-sampah tersebut dapat berasal dari darat seperti halnya dalam aktivitas konsumsi cepat saji, aktivitas wisata, sapuan runoff dari jalan-jalan dan saluran pembuangan (Ocean Conservancy, 2007; Sul et al., 2011; Jang et al., 2014).

Kelas plastik lunak, busa dan plastik keras merupakan kelas sampah yang paling mendominasi di kawasan TNBB dengan persentase masing-masing sebesar $45,1 \%, 30,8 \%$ dan $12,4 \%$. Ketiga kelas sampah tersebut juga mendominasi di seluruh kawasan pesisir pulau Bali berdasarkan penelitian dari Hendrawan et al. (2019), dengan persentase masing-masing sebesar 45\%, $13 \%$ dan $15 \%$. Hal ini dapat menjadi indikasi bahwa ketiga kelas sampah tersebut belum terkelola dengan baik di berbagai kawasan dan aktivitas, sehingga berakhir dengan mencemari kawasan pesisir pulau Bali termasuk kawasan konservasi TNBB. Kondisi di kawasan konservasi lain juga mengalami hal serupa, sebagaimana pada kawasan konservasi penyu di Timur Laut Brazil yang mana sampah plastik juga merupakan sampah dominan dengan proporsi 52-94\% (Sul et al., 2011). Selain itu, penelitian lain juga menunjukkan bahwa plastik merupakan jenis sampah dominan (Tabel 1).

Tabel 1. Perbandingan hasil penelitian terkait dengan sampah laut

\begin{tabular}{|c|c|c|c|}
\hline Lokasi & Konsentrasi & Sampah dominan & Sumber \\
\hline \multicolumn{4}{|l|}{ Sediment } \\
\hline $\begin{array}{c}\text { Beach, Taman Nasional Bali } \\
\text { Barat }\end{array}$ & $0,05-28,47$ items $/ \mathrm{m}^{2}$ & Soft plastic $(44,8 \%)$ & Hasil penelitian ini \\
\hline Beach, Ambon & $0.722-5$ items $/ \mathrm{m}^{2}$ & Plastic film (63-91\%) & Manullang (2019) \\
\hline $\begin{array}{c}\text { Beach, Sebatik Island, Sabah } \\
\text { Area }\end{array}$ & $1-515$ items $/ \mathrm{m}^{2}$ (perclass) & Plastic $(40 \%)$ & Estim \& Sudirman (2017) \\
\hline Beach, Baleric island & $\begin{array}{c}4-59 \text { items } / \mathrm{m}(\text { Mean } \\
\text { concentration } 36 \text { items } / \mathrm{m})\end{array}$ & Cigarette \& Plastic (46\% \& 67\%) & Ribes et al. (2007) \\
\hline $\begin{array}{c}\text { Estuary, Mangrove Pantai } \\
\text { Indah kapuk, Jakarta }\end{array}$ & $20-533$ items $/ \mathrm{m}^{2}$ & Plastic $(77.7 \%)$ & Hastutiet al. (2014) \\
\hline Beach, Korea & 0.5 items $/ \mathrm{m}^{2}$ & Fiber \& Fabric (55\%) & Jang et al. (2014) \\
\hline $\begin{array}{c}\text { Beach, NE Brazil Sea Turtle } \\
\text { Conservation Area }\end{array}$ & $2-8$ items $/ \mathrm{m}$ & Plastic $(52-94 \%)$ & Sul et al. (2011) \\
\hline \multicolumn{4}{|l|}{ Surface water } \\
\hline $\begin{array}{l}\text { Pelagos Sanctuary, } \\
\text { Mediterranean Sea }\end{array}$ & $\begin{array}{c}0.0126 \text { items } / \mathrm{m}^{2}-175,2 \\
\text { items } / \mathrm{km}^{2}\end{array}$ & Meso \& Macroplastic (78.5-83.4\%) & Fossi et al. (2017) \\
\hline Sebatik Island, Sabah Area & $5.6-44$ items $/ \mathrm{m}^{2}$ & Plastic $(41.7 \%)$ & Estim \& Sudirman (2017) \\
\hline
\end{tabular}


Sampah plastik secara konsisten dapat ditemukan di kawasan Bali Barat dan kawasan Pulau Menjangan (Gambar 5). Ketiga kelas sampah dominan ditemukan di kedua kawasan dengan kecenderungan jumlah yang berbeda. Di kawasan Bali Barat, sampah busa/foam merupakan kelas sampah terbanyak yaitu sebesar 1.693 buah sampah dengan jumlah jenis sampah berurutan dari yang tertinggi hingga yang terendah yaitu wadah makanan foam, polystyrene, gelas dan busa tidak diketahui. Diikuti oleh kelas plastik lunak (pembungkus makanan/label, plastik pembungkus, gelas, sedotan dll.) sebanyak 1.415 buah dan plastik keras (unknown/other, perkakas makanan, tutup botol, stik lolipop/pembersih telinga dll.) sebanyak 500 buah.

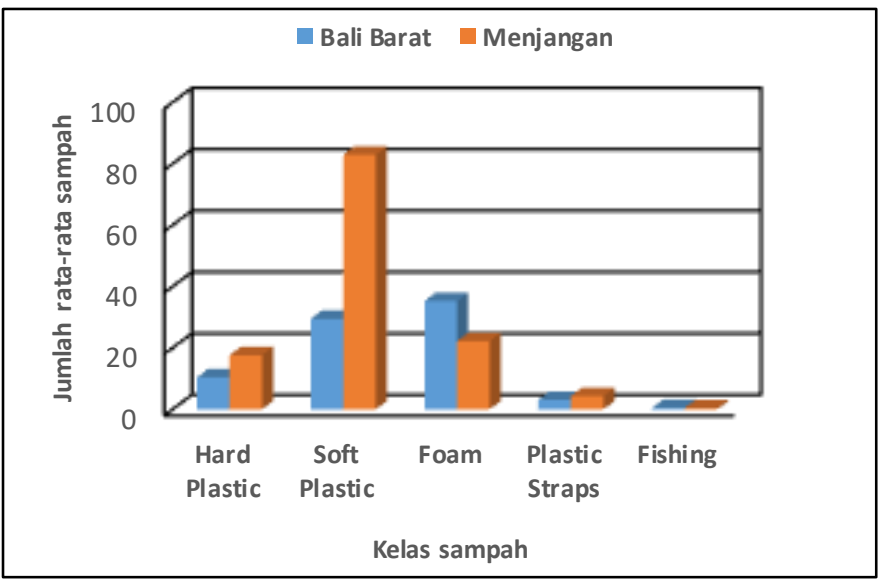

Gambar 5. Rata-rata jumlah kelas sampah plastik pada tiap transek di kawasan Bali Barat dan kawasan Pulau Menjangan.

Di sekeliling dan sepanjang garis pantai kawasan Bali Barat terdapat beberapa aktivitas dan kawasan yang berpotensi memiliki peran sebagai penyumbang sampah, seperti halnya aktivitas penyeberangan (pelabuhan), aktivitas perikanan, beberapa kawasan wisata, permukiman dan masukan sungai. Sebagaimana busa wadah makanan dan gelas kerap kali dijumpai dalam aktivitas konsumsi masyarakat, seperti halnya pada kawasan permukiman, aktivitas wisata dan aktivitas penyeberangan di kawasan Bali Barat. Sedangkan sampah polystyrene biasa digunakan dalam aktivitas perikanan sebagai box/pelampung dan juga dalam pengepakan barang. Begitu juga pada kelas sampah plastik lunak dan plastik keras yang mana biasa digunakan di kawasan permukiman, wisata, penyeberangan dan kawasan komersial lainnya. Sampah busa di kawasan Bali Barat memiliki bentuk yang beragam, jenis polystyrene dapat berupa pelampung, dan sampah gelas busa dapat berupa kemasan mie instan dengan bentuk utuh (Gambar 6).

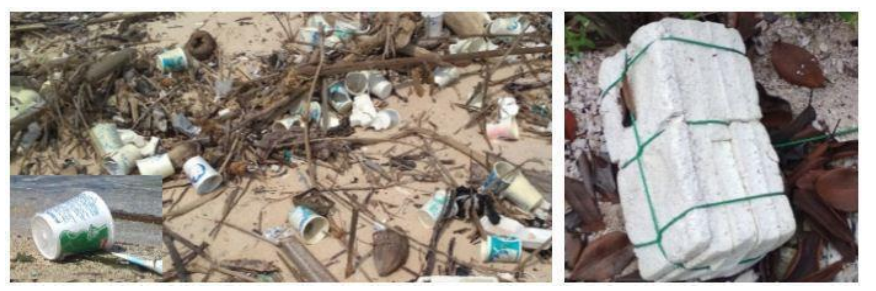

Gambar 6. Sampah busa (foam) di kawasan TNBB bagian Bali Barat

Berbeda dari kawasan Bali Barat, sampah tertinggi di kawasan Pulau Menjangan berasal dari kelas plastik lunak yaitu sebanyak 1.743 buah sampah, diikuti oleh kelas busa sebanyak 466 buah dan sampah plastik keras sebanyak 370 buah. Di sepanjang garis pantai Pulau Menjangan hanya terdapat aktivitas wisata dan juga tempat ibadah keagamaan yang mana pada waktu tertentu pulau akan dikunjungi oleh banyaknya kerumunan massa, hal ini juga dapat berpotensi sebagai jalur masuknya sampah ke lingkungan laut (Kadir et al. 2015). Selain itu, posisi Pulau Menjangan relatif dekat dengan Pulau Bali dan Pulau Jawa yang juga berpotensi sebagai sumber masukan sampah terkait dengan keberadaan kawasan padat penduduk dan aliran sungai di sana. Sebagaimana berdasarkan jenis sampah yang ditemukan, terdapat indikasi bahwa sampah dapat berasal dari aktivitas konsumsi masyarakat, baik di kawasan permukiman, kawasan wisata, maupun keberadaan sungai sebagai jalur masuknya sampah ke lingkungan laut.

Berdasarkan 10 besar jenis sampah terbanyak di TNBB secara keseluruhan, peringkat tertinggi sampah pada kawasan diduduki oleh plastik sekali pakai yang tidak terkelola dengan baik dan teridentifikasi sebagai sampah konsumsi masyarakat (Tabel 2).

Tabel 2. 10 besar jenis sampah terbanyak di kawasan TNBB.

\begin{tabular}{|c|c|c|}
\hline Urutan & Jenis sampah & Kelas sampah \\
\hline 1 & $\begin{array}{c}\text { Pembungkus } \\
\text { makanan/label }\end{array}$ & $\begin{array}{c}\text { Plastik lunak } \\
\text { (soft plastic) }\end{array}$ \\
\hline 2 & Wadah makanan & Busa (foam) \\
\hline 3 & $\begin{array}{c}\text { Plastik pembungkus } \\
\text { (sheeting) }\end{array}$ & $\begin{array}{c}\text { Plastik lunak } \\
\text { (soft plastic) }\end{array}$ \\
\hline 4 & Polystyrene & Busa (foam) \\
\hline 5 & Gelas/tutup gelas plastik & $\begin{array}{c}\text { Plastik lunak } \\
\text { (soft plastic) }\end{array}$ \\
\hline 6 & $\begin{array}{c}\text { Gelas/piring/ } \\
\text { mangkuk }\end{array}$ & Busa (foam) \\
\hline 7 & Sedotan & $\begin{array}{c}\text { Plastik lunak } \\
\text { (soft plastic) }\end{array}$ \\
\hline 8 & $\begin{array}{c}\text { Tidak diketahui/sampah } \\
\text { keras lain }\end{array}$ & $\begin{array}{c}\text { Plastik keras } \\
\text { (hard plastic) }\end{array}$ \\
\hline 9 & Tali/tali tambang/pita & Tali (string/rope) \\
\hline 10 & $\begin{array}{c}\text { Tidak diketahui/sampah } \\
\text { lunak lain }\end{array}$ & $\begin{array}{c}\text { Plastik lunak } \\
\text { (soft plastic) }\end{array}$ \\
\hline
\end{tabular}

Bilamana sampah plastik kategori plastic straps (string/rope/ribbon \& packing strap), hard plastic (crate/bucket), foam (polystyrene \& unknown) dan fishing (net \& buoys) diasumsikan berasal dari laut dan kategori lainnya dianggap 100\% berasal dari sumber darat berdasarkan pengkategorian sumber jenis sampah pada penelitian dan laporan dari (Ocean conservancy, 2007 ; OSPAR, 2009; Ribic et al., 2010; Jang et al., 2014), maka sebanyak $84 \%$ sampah plastik di kawasan TNBB dapat bersumber dari sumber darat dan sebanyak $16 \%$ sampah plastik di kawasan TNBB dapat berasal dari sumber laut

\subsubsection{Bentuk dan Ukuran Sampah}

Di lingkungan, sampah akan berubah menjadi bentuk yang lebih kecil seiring dengan berjalannya waktu seperti halnya sampah plastik yang dapat mengalami fragmentasi menjadi bagian-bagian kecil yang disebabkan oleh paparan sinar UV dan pengikisan sampah (Zarfl et al., 2011). Sampah laut di TNBB dominan memiliki ukuran 8-16 cm (32\%), 16-21 cm (21\%) dan ukuran >21 $\mathrm{cm}(17 \%)$. Kemudian diikuti oleh sampah berukuran $4-8 \mathrm{~cm}$ (16\%), 2-4 cm (11\%), 1-2 cm (2\%) dan 0-1 cm (1\%) (Gambar 7a). Dari 7.009 sampah yang terdata, sebanyak 4.058 sampah berbentuk utuh $(57,9 \%)$, dan 2951 sampah berbentuk tidak utuh $(42,1 \%)$. Sampah berbentuk utuh didominasi oleh kelas sampah hard plastic, soft plastic, metal, glass, rubber, paper dan other. Sedangkan sampah berbentuk tidak utuh mendominasi pada kelas plastic straps, fishing, foam, cloth, timber, other dan miscellaneous (Gambar 7b). 


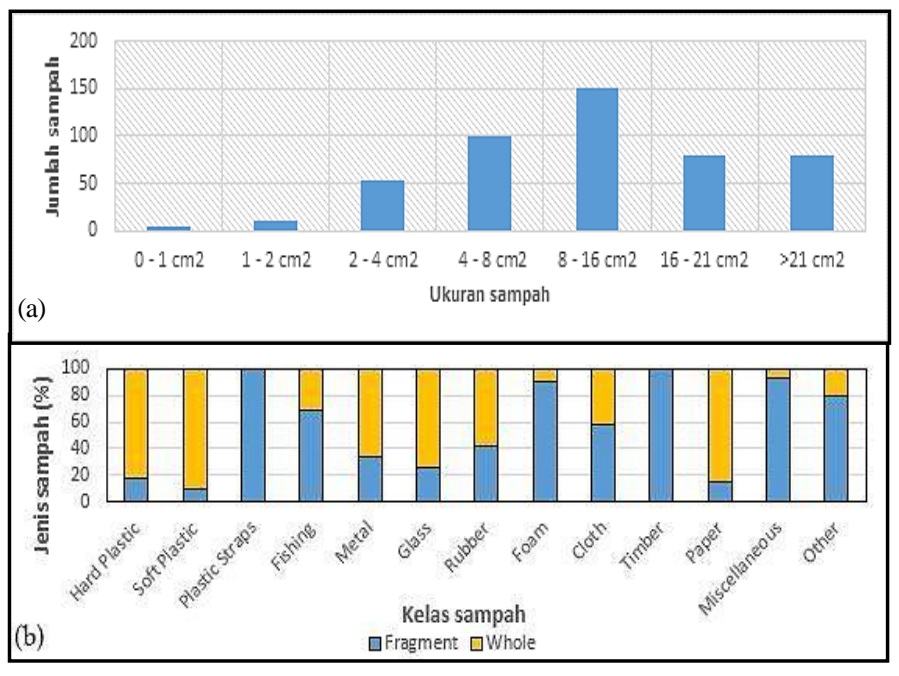

Gambar 7. Jumlah sampah pada tiap kelas ukuran (a) dan persentase bentuk pada tiap kelas sampah (b).

Bentuk dan ukuran sampah di lingkungan tergantung pada lama waktu sampah berada di lingkungan laut, faktor lingkungan dan juga bagaimana bentuk sampah tersebut pada saat masuk ke dalam lingkungan. Sampah dalam kondisi utuh ditemukan lebih banyak walaupun rasio dengan sampah tidak utuh tidak terlalu jauh yakni sebesar 1,4:1. Banyaknya sampah berbentuk utuh dapat mengindikasikan bahwa sampah di TNBB relatif belum lama masuk ke lingkungan laut dan juga dapat bersumber dari sumber lokal. Sebagaimana sampah dapat berubah menjadi bagian-bagian kecil seiring dengan berjalannya waktu sehingga proporsi sampah terfragmentasi akan terus meningkat terhadap total sampah laut (Zarfl et al., 2011; Andrady, 2011).

Selain itu sampah busa/foam merupakan sampah yang mudah hancur di lingkungan laut (Jang et al., 2014), sehingga sampah busa yang tercatat di TNBB dominan memiliki bentuk tidak utuh. Meskipun begitu, keberadaan sampah busa berbentuk utuh juga banyak ditemukan di sepanjang kawasan pesisir TNBB yaitu berupa sampah kemasan mie instan (Gambar 6). Hal ini juga mengindikasikan bahwa terdapat sumber lokal sampah di TNBB, yang mana sampah relatif belum lama masuk ke lingkungan laut berdasarkan keutuhan bentuknya.

Daya apung dan ukuran sampah dapat berpengaruh pada kemampuan sampah untuk tersebar jauh dari sumbernya. Adapun daya apung dipengaruhi oleh ukuran, bentuk, volume serta densitas sampah (Ryan, 2015). Ukuran sampah dominan di TNBB memiliki ukuran yang relatif besar (ukuran 8 hingga $>21 \mathrm{~cm}$ ) dengan proporsi $70 \%$. Hal ini dapat mengindikasikan bahwa sampah di kawasan TNBB dapat bersumber dari sumber lokal dan sumber yang berada jauh dari kawasan. Sebagaimana berdasarkan temuan Fazey dan Ryan (2016), sampah dengan ukuran dan daya apung yang lebih besar mampu tersebar lebih jauh dibandingkan dengan sampah berukuran kecil. Sampah berukuran kecil cenderung tenggelam sebelum menyebar jauh ke laut (Fazey dan Ryan, 2016). Sehingga dengan begitu sampah berukuran relatif kecil di kawasan TNBB dapat berasal dari sumber lokal dan sampah dengan ukuran relatif besar dapat berasal dari sumber lokal dan sumber yang berada jauh dari kawasan berdasarkan kemampuannya untuk tersebar.

Sampah dominan di TNBB berupa plastik yang pada umumnya memiliki densitas lebih rendah dibandingkan dengan densitas air laut (Ryan, 2015), dengan begitu sampah plastik dapat tersebar dengan mudah dan dapat ditemukan di seluruh sisi pesisir kawasan TNBB. Disamping itu walaupun bentuk dan ukuran sampah mempengaruhi daya apung dan kemampuannya untuk tersebar, tentu saja untuk memahami persebaran dan sumber sampah di
TNBB dengan baik diperlukan pengetahuan lebih lanjut mengenai pola transportasi sampah berdasarkan faktor fisik, kimia dan biologi laut di lingkungan sekitar kawasan TNBB. Seperti halnya pengaruh angin, arus, gelombang, pasang surut, perubahan densitas sampah akibat fouling, pengaruh transportasi organisme dan lain sebagainya (Sebille et al., 2020).

Kesadaran masyarakat akan sampah memainkan peranan penting untuk mengurangi pencemaran sampah laut di kawasan pesisir Taman Nasional Bali Barat, mengingat bahwa 10 besar sampah yang paling umum ditemukan di kawasan TNBB merupakan sampah konsumsi masyarakat. Langkah preventif berupa pengelolaan, penekanan penggunaan plastik dan praktik pembuangan sampah sembarangan secara luas dimungkinkan dapat menjadi langkah yang menjanjikan. Sebagaimana di sekitar kawasan TNBB terdapat beberapa sungai, permukiman, aktivitas wisata dan aktivitas pelabuhan yang mungkin memiliki potensi sebagai akses masuknya sampah ke lingkungan. Seperti halnya sungai di Bali, sebanyak 425 ton sampah per hari terbuang ke lingkungan sungai, yang mana sebanyak 33 ton sampah merupakan sampah plastik (Bali Partnership, 2019).

Dalam membatasi pencemaran sampah di Bali, Gubernur Bali telah menetapkan beberapa peraturan yang mendukung pembatasan timbulan sampah, yaitu Peraturan Gubernur Bali No.97/2018 tentang Pembatasan Timbulan Sampah Plastik Sekali Pakai (PSP). Dalam peraturan ini seluruh pihak dilarang menggunakan plastik sekali pakai (plastik kresek, polystyrene dan sedotan) serta wajib untuk menggunakan produk pengganti PSP. Kemudian Peraturan Gubernur Bali No.47/2019 tentang pengelolaan sampah berbasis sumber. Secara umum, peraturan ini menegaskan bagaimana seharusnya pengelolaan sampah dilakukan dari sumber, yang mana pada tiap sumber wajib memilah sampah menjadi beberapa bagian, diantaranya adalah sampah terurai, sampah sulit terurai, sampah B3 dan sampah residu. Sampah terurai dapat diolah secara mandiri atau bekerja sama dengan Tempat Pengolahan Sampah Reuse, Reduce, Recycle (TPS 3R), sementara sampah sulit terurai dapat dikirimkan ke Bank sampah dan Fasilitas Penampungan Sampah (FPS). Kemudian sampah B3 dapat dikirimkan ke TPS $3 \mathrm{R}$ dan untuk sampah residu dapat ditempatkan pada tempat sampah dan berakhir di Tempat Pemrosesan Akhir (TPA).

\section{Kesimpulan}

Kesadaran masyarakat dan implementasi Peraturan Gubernur Bali tentang pengelolaan sampah berbasis sumber dan pembatasan timbulan sampah PSP oleh berbagai pihak secara luas dimungkinkan dapat memiliki peran penting dalam menekan sebaran sampah di kawasan pesisir TNBB, begitu juga di sepanjang garis pantai pulau Bali. Sebagaimana sampah yang berasal dari aktivitas konsumsi masyarakat merupakan sampah yang umum dijumpai di kawasan TNBB. Terdapat kemungkinan bahwa sampah berasal dari sumber lokal di sekitar kawasan TNBB bila ditinjau berdasarkan jenis, ukuran dan bentuk sampah yang ditemukan. Sehingga selanjutnya peninjauan perihal pengelolaan dan perilaku masyarakat terhadap sampah di kawasan permukiman, kawasan wisata, aktivitas pancing dan juga aktivitas penyeberangan yang berada di sekitar kawasan TNBB perlu untuk dilakukan.

\section{Ucapan Terima Kasih}

Penulis mengucapkan terima kasih kepada pihak Balai Taman Nasional Bali Barat atas segala bentuk dukungan yang diberikan selama penelitian berlangsung. 


\section{Daftar Pustaka}

[DLH] Dinas Lingkungan Hidup Provinsi Jawa Timur. 2017. Dokumen Informasi Kinerja Pengelolaan Lingkungan Hidup Daerah Provinsi Jawa Timur Tahun 2017. Surabaya: DLH. 22 p.

[DPS] Direktorat Pengelolaan Sampah. 2018. Sumber Sampah Periode 2017 2018. Sistem Informasi Pengelolaan Sampah http://sipsn.menlhk.go.id/?q=3a-sumbersampah\&field_f_wilayah_tid $=1748 \&$ field_kat_kota_tid=All\&field_p eriode_id_tid=2168. [10 Agustus 2020]

[KKP] Kementerian kelautan dan Perikanan. 2017. Luas Kawasan Konservasi Perairan, Pesisir dan Pulau-Pulau Kecil di Indonesia Tahun 2017. Tabel Informasi Luas Kawasan Konservasi. http://www.kkji.kp3k.kkp.go.id/index.php/91-tentang konservasi/tentang-berita/118-tabel-luas-kawasan-konservasi November 2019]

[SCBD] Secretariat of the Convention on Biological Diversity. 2016. Marine debris: Understanding, Preventing and Mitigating the Significant Adverse Impacts On the Significant Adverse Impacts on Marine and Coastal Biodiversity. Montreal: SCBD. $78 \mathrm{p}$

[UN] United Nations. 2012. Report of the United Nations Conference on Sustainable Development. New York: UN. 92 p.

[UNEP] United Nations Environment Programme. 2011. UNEP Year Book: Emerging Issues in our Global Environment. Nairobi (KE): UNEP. 92

[UNEP] United Nations Environment Programme. 2014. UNEP Year Book: Emerging Issues in our Global Environment. Nairobi (KE): UNEP. 71 $\mathrm{p}$

Abentin Estim and Rafidah Sudirman. 2017. Types and abundance of macroand micro-marine debris at Sebatik Island, Tawau, Sabah. Borneo Journal of Marine Science and Aquaculture Vol.1:57-64

Andrady AL. 2011. Microplastic in the Marine Environment. Marine Pollution Bulletin Vol.62: 1596-1605

Bali Partnership, 2019. Workshop kerjasama pengelolaan sampah plastik pesisir dan laut. Kantor Gubernur Bali.

Barnes DKA, Galgani F, Thompson RC, Balraz M. 2009. Accumulation and Fragmentation of Plastic Debris in Global Environment. Philosophical Transactions of Royal Society Vol. 364: 1985-1998

C Y Manullang. 2019. The abundance of Plastic Marine Debris on Beaches in Ambon Bay. IOP Conf. Ser. Earth Environ. Sci. 253012037

Fossi MC, et al. 2017. Plastic debris occurrence, convergence areas and fin whales feeding ground in the Mediterranean marine protected area Pelagos Sanctuary: A modeling approach. Frontiers in Marine Science Vol.4: 1-16

Fazey MFC, Ryan PG. 2016. Debris Size and Buoyancy Influence The Dispersal Distance of Stranded Litter. Marine Pollution Bulletin. Vol. 110(1):371-377

Galgani F et al. 2000. Litter on the Sea Floor along European Coasts. Marine pollution bulletin Vol. 40: 516-527

Hastuti A, Yulianda F, Wardiatno Y. 2014. Distribusi spasial sampah laut d ekosistem mangrove Pantai Indah Kapuk, Jakarta. Bonorowo Wetlands Vol.4 (2): 94-107

Hendrawan IG, Karidewi MP, Pratama GIP, Maharta IPRF, Adibhusana MN 2019. Survey dan Monitoring Sampah Laut Pesisir Bali. Denpasar: WWF Indonesia. $56 \mathrm{p}$

Jambeck JR, et al. 2015. Plastic waste inputs from land into the ocean. Science Vol.347 (6223): 768-771

Jang YC et al. 2014. Sources of plastic marine debris on beaches of Korea: More from the ocean than the land. Ocean Sci. Vol. 49(2): 151-162

Kadir AA, Hasni AF, Sarani NA. 2015. Marine Debris Composition in Batupahat, Johor: A Comparison between Sungai Lurus and Minyakbeku Beach. ARPN Journal of Engineering and Applied Sciences. Vol. 10(15): ISSN 1819-6608

Lippiatt, Sherry, Sarah O, Courtney A. 2013. Marine Debris Monitoring and Assessment. USA: NOAA Technical Memorandum NOS-OR\&R-46. $88 \mathrm{p}$

Li EAL. 2000. Optimum Harvesting with Marine Reserves. North American Journal of Fisheries Management Vol. 20: 882-896.

Mahmud A, Satria A, Kinseng RA. 2016. Zonasi Konservasi untuk Siapa? Pengaturan Perairan Laut Taman Nasional Bali Barat. Jurnal Ilmu Sosial dan Politik Vol.18 (3): 237.

MPAnews. December 2011. Marine Debris and MPAs: Managing the Impacts of Litter on Marine Ecosystems. New York: MPAnews. 8 p
Ocean Conservancy. 2007. International Coastal Cleanup Report 2007: Start a Sea Change. Washington: Ocean Conservancy. $87 \mathrm{p}$

OSPAR. 2009. Marine litter in the North-East Atlantic Region, Assessment and priorities for response. United Kingdom: OSPAR commission. 127 hlm

Peraturan Gubernur Provinsi Bali Nomor 97 Tahun 2018 tentang Pembatasan Timbulan Sampah Plastik Sekali Pakai

Peraturan Gubernur Provinsi Bali Nomor 47 Tahun 2019 tentang Pengelolaan Sampah Berbasis Sumber

Purba NP, Syamsuddin ML, Sandro R, Pangestu IF, Prasetio MR. 2017. Distribution of Marine Debris in Biawak Island, West Java, Indonesia. World Scientific News Vol. 66: 281-292

Pawar PR, Shirgaonka SS, Patil RB. 2016. Plastic marine debris: Sources, distribution and impacts on coastal and ocean biodiversity. PENCL Publication of Biological Sciences Vol. 3(1): 40-54.

Ribes L, Basterretxea G, Palmer M, Tintore J. 2007. Origin and abundance of beach debris in the Balearic Islands. SCI. MAR. Vol.71 (2): 305-314. ISSN: 0214-8358

Ribic CA, Sheavly SB, Rugg DJ, Erdmann ES. 2010. Trends and drivers of marine debris on the Atlantic coast of the United States 1997-2007. Marine Pollution Bulletin Vol.60: 1231-1242

Ryan PG. 2015. Does Size and Buoyancy Affect the Long-distance Transport of Floating Debris?.Environ. Res. Lett. 10 (2015) 084019

Schuyler Q, Willis K, Lawson TJ, Mann V, Wilcox C. 2018. Handbook of Survey Methodology Plastics Leakage (developed for CSIRO Global Plastic Pollution Project). Australia: CSIRO ePublish EP178700. $52 \mathrm{p}$

Sul JA, Santos IR, Friedrich AC, Matthiesen A, Fillmann G. 2011. Plastic Pollution at a Sea Turtle Conservation Area in NE Brazil: Contrasting Developed and Undeveloped Beaches. Estuaries and Coasts Vol.34: 814-823

Sebille EV. 2020. The Physical Oceanography of the Transport of Floating Marine Debris. Environ. Res. Lett. 15023003

Thompson $\mathrm{R}$ et al. 2004. Lost At Sea: Where is all the plastic?.Science Vol.304: $838-838$

Zarfl C et al. 2011. Microplastics in Oceans. Mar Pollut Bull Vol. 62(8):15891591 